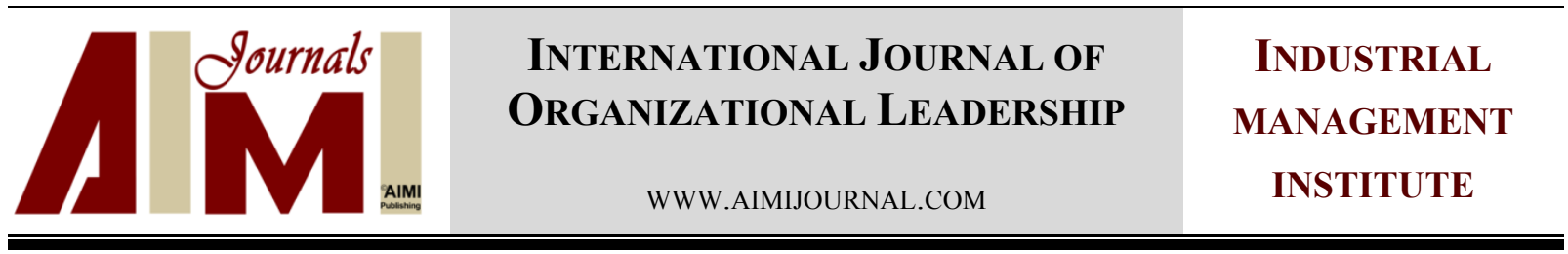

\title{
The effect of market structure and risk taking on the efficiency of banks accepted in Tehran stock exchange
}

\author{
Taha Saadati Sharafeh ${ }^{1}$, Sirous Fakhimi $\operatorname{Azar}^{2} *$ \\ ${ }^{1}$ Department of Management and Accounting, East Azerbaijan Science and Research Branch, Islamic Azad \\ University, Tabriz, Iran \\ ${ }^{2}$ Department of Management and Accounting, Tabriz Branch, Islamic Azad University, Tabriz, Iran
}

\begin{tabular}{ll}
\hline & ABSTRACT \\
\cline { 2 - 3 } & \\
Keywords: & $\begin{array}{l}\text { The present study aimed to investigate the effect of market structure and risk taking on the } \\
\text { efficiency of banks accepted in Tehran Stock Exchange. This study was an applied research } \\
\text { and all the banks accepted in Tehran Stock Exchange participated in the study and among } \\
\text { Taking }\end{array}$ \\
$\begin{array}{l}\text { them, } 10 \text { banks were selected as the sample of the study which was examined over the period } \\
\text { of } 5 \text { years. To test the hypotheses, multivariate linear regression test was used. The current } \\
\text { study had one main hypothesis and } 4 \text { sub-hypotheses. The findings revealed that the market } \\
\text { structure and risk taking had significant positive relation with efficiency of banks accepted in }\end{array}$ \\
$\begin{array}{l}\text { Tehrespondence: } \\
\text { fakhimiazar@iaut.ac.ir }\end{array}$
\end{tabular}

(C)AIMI Journals

Financial economists have accomplished various surveys concerning the relation between market structure and risk-taking on the efficiency of banks at the international level in recent years. Commonly, corporate financing decisions and the manner of product market have been investigated separately. A large part of research in financial economics has assumed that there is a relationship between market structure and capital structure; however, the financial management of corporations is not same in international field and removing country type depend on the culture, legal systems, financial organizations or institutions, and institutional development stage. Therefore, the researchers in different geographical locations analyze the effect of market structure and risk taking on the efficiency of banks. This study aimed to investigate the effect of market structure and risk taking on the efficiency of banks accepted 
in Tehran Stock Exchange to provide a multidimensional perspective to address market structure and risk taking and measure the relative efficiency of different banks in different conditions. The effective interaction between capital structure, representative theory, and bankruptcy theory causes the combined applicability of theories for analyzing the capital structure in the different stages of market. Thus, the present study tried to criticize the recent perspective regarding the analysis of market structure and presented a new perspective on the non-linear relationship of market structure and risk taking on the efficiency of banks and analysis of related theories.

\section{The Literature Review}

The analysis of competitive market structure is an important area of marketing research due to its significance in explaining the nature and extent of competition among companies and their products in different fields (Bremus, 2015; Chung \& Chuwonganant, 2014; Elrod et al., 2002; Jerbashian, 2011; Jolly, 1998). The impact of market structure on bank efficiency has been widely tested based on the theories of structure-conduct-performance (SCP), relative market power hypothesis (RMP), and the quiet life hypothesis (QLH) (Claeys \& Vander Vennet, 2008; Demirguc-Kunt, Laeven, \& Levine, 2004; Heffernan, 2005; Kapopoulos \& Siokis, 2005; Maudos \& De Guevara, 2007; Tregenna, 2009).

Bagherzadeh (2003) surveyed the model of capital structure of companies accepted in Tehran Stock Exchange. He investigated the capital structure of 158 productive companies in the time interval from 1998 to 2002 and found that there was a positive relationship between profitability and tangible fixed assets and furthermore, there was a direct relationship between the size of company and debt ratio. Daryabar, Dehghantanha, and Udzir (2011) studied the effective factors on the capital structure of companies accepted in Tehran Exchange Stock using the least squares regression model. They found that there was a negative relationship between capital structure and profitability indicators and growth opportunities and there was a positive relationship between capital and ownership structures. Brander and Lewis (1986) and Maksimovic (1988) provided a theoretical framework regarding the relationship between capital structure and market structure. They stated that the market structure is effective on the capital structure and this effectiveness emerged through the competitive behavior and company's strategies. Chevalier (1993) presented supporting evidences for negative relationship between capital and market structures. These results were consistent with the bankruptcy costs or hypotheses related to hierarchical theories and information asymmetry. Pandey (2004) surveyed the relationship between capital and market structures. He analyzed this relationship in Malaysian companies using a static and dynamic panel data analysis and stated that there was a nonlinear relationship between capital and market structures. He certified the hypotheses of being cubic relationship $\left(3^{\text {rd }}\right.$ degree cubic equation) between capital structure and market structure and existence of parabolic relationship between capital structure and profitability structure through implementing extended torque system.

\section{Research Hypotheses}


The following hypotheses guided the study:

$\mathbf{H}_{1}$ : The inflation rate affects banks' assets return rate.

$\mathbf{H}_{2}$ : The inflation rate affects banks' shareholders return rights rate.

$\mathbf{H}_{3}$ : Exchange rates changes and interest rates changes affects banks assets return rate.

$\mathbf{H}_{4}$ : Exchange rates changes and interest rates changes affects banks' shareholders return rights rate.

\section{Method}

This applied study used an ex post facto method to investigate the performance of banks accepted in Tehran Exchange Stock. The population for the current study consisted of all banks employees. The current researchers tried to compare and survey the relationships among special factors or variables in preexisting groups of employees with similar backgrounds who were exposed to different conditions through studying their results. This study was conducted to investigate the effect of market structure and risk taking on efficiency of banks for five years starting from 2009 to 2013. In this study, banks efficiency was considered as a dependent variable and market structure and risk taking as independent variables. The size of company, financial index, and liquidity ratio were control variables of the present paper. The factors such as return on assets (ROA) and return on equity (ROE) were used for estimating the efficiency of banks. ROA equals net income was divided by average total assets while ROE equals net income was divided by its average stockholder's equity. To assess market structure, the index inflation rate was used that the central bank proclaims it every year. In this research, for risk taking, two indicators of profit rate changes and currency rate changes were used which were extracted from central bank websites. The size of bank was estimated by sale or property variables. This is done to control the effect of size on the wealth creation through economies of scale, monopoly power and bargaining power. The following formula was used to estimate the size of bank. In this formula, Size ${ }_{i t}$

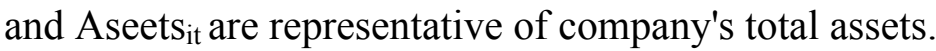

$$
\text { Size }_{\text {it }}=\log \left(\text { Aseets }_{\text {it }}\right)
$$

Financial leverage (LEV) is calculated by dividing the total liabilities (TL) to total assets (TA) (Akbari, 2011). LEV can be computed by using the following formula:

$$
\mathrm{LEV}=\mathrm{TL} / \mathrm{TA}
$$

Liquidity ratios attempt to measure bank's ability to pay off its short-term debt obligations.

\section{LIQ = Current Assets / Current Liabilities}

The statistical population of the study consisted of banks which were accepted in Tehran Exchange Stock and the end of their fiscal year was at the end of Esfand, their financial information presented completely in a time interval which was started from 2009 to 2013, 
their stock trading was done more than three months about the mentioned shares constantly without any trading pause, and the company did not have any changes in its fiscal year.

\section{Results}

Concerning the normality of the data for the inflation rate (dependent variable), multivariate regression could be used for testing the first hypothesis. Table 1 presents the results of multivariate regression coefficient analysis.

Table 1

Multivariate Regression Coefficient Analysis

\begin{tabular}{lccccc}
\hline \multirow{2}{*}{ Predictor Variables } & \multicolumn{2}{c}{ Non-standard Coefficients } & Standard Coefficients & t-ratio & Significance Level \\
& $\beta$ & SE & Beta & & \\
\hline Fixed & 23.102 & 2.371 & & 9.745 & 0.000 \\
Inflation Rate & -0.162 & 0.042 & -0.333 & -3.873 & 0.000 \\
The Size of Banks & -0.342 & 0.205 & -0.119 & -1.663 & 0.103 \\
Financial Leverage & -20.123 & 2.293 & -0.657 & -8.777 & 0.000 \\
Liquidity Ratio & 1.516 & 2.865 & 0.043 & 0.529 & 0.599 \\
\hline
\end{tabular}

According to the significant level of error for regression test, there was a significant negative relationship between inflation rate and banks' assets returns rate with 99 per cent confidence level. The results revealed that inflation rate $(-0.33)$, the size of banks $(-0.11)$, financial leverage (-0.65), and liquidity ratio (0.04) could predict banks' assets returns rate. Table 2 presents the results of multivariate regression coefficient analysis of second hypothesis. According to the negative slope of standard regression coefficient (Beta) and tratio, there was a negative significant relationship between inflation rate and return of equity of banks' shareholders and inflation rate, size of banks, financial leverage, and liquidity ratio could predict return of equity of banks' shareholders.

Table 2

Multivariate Regression Coefficient Analysis

\begin{tabular}{lccccc}
\hline Predictor Variables & Non-standard & Coefficients & Standard Coefficients & t-ratio & Significance Level \\
& $\beta$ & SE & 26.484 & Beta & 0.966 \\
Fixed & 25.580 & 0.468 & -0.626 & -4.045 & 0.339 \\
Inflation Rate & -1.895 & 2.294 & -0.202 & -1.572 & 0.000 \\
The Size of Banks & -3.607 & 25.612 & 0.148 & -098 & 0.123 \\
Financial Leverage & 28.133 & 32.001 & -0.102 & -0.706 & 0.484 \\
Liquidity Ratio & -22.604 & & & & 0.278 \\
\hline
\end{tabular}

According to the negative slope of standard regression coefficient (Beta) and t-ratio, it could be deduced that there was an inverse relationship between predicators and criterion variables, that is, higher scores on changes in exchange rates and in interest rates predicated lower scores on return on banks' assets.

Table 3 represents the results of multivariate regression coefficient analysis for third hypothesis. 
Table 3

Multivariate Regression Coefficient Analysis

\begin{tabular}{lccccc}
\hline Predictor Variables & $\begin{array}{c}\text { Non-standard } \\
\beta\end{array}$ & $\begin{array}{c}\text { Coefficients } \\
\text { SE }\end{array}$ & $\begin{array}{c}\text { Standard Coefficients } \\
\text { BETA }\end{array}$ & t-ratio & Significance Level \\
\hline Fixed & 21.813 & 3.907 & & 5.582 & 0.000 \\
Exchange Rate Changes & 0.167 & 0.064 & 0.211 & 2.622 & 0.012 \\
Interest Rate Changes & 0.083 & 0.085 & 0.112 & 0.982 & 0.331 \\
The Size of Banks & -0.269 & 0.296 & -0.094 & -0.911 & 0.367 \\
Financial Leverage & -19.888 & 2.726 & -0.650 & -7.295 & 0.000 \\
Liquidity Ratio & -0.958 & 3.112 & -0.027 & -0.308 & 0.760 \\
\hline
\end{tabular}

Table 4 exhibits the results of multivariate coefficient analysis for fourth hypothesis which states that exchange rates change and interest rates changes affects banks' shareholders return rights rate.

Table 4

Multivariate Regression Coefficient Analysis

\begin{tabular}{lccccc}
\hline \multicolumn{1}{c}{ Predictor Variables } & $\begin{array}{c}\text { Non-standard } \\
\beta\end{array}$ & $\begin{array}{c}\text { Coefficients } \\
\text { SE }\end{array}$ & $\begin{array}{c}\text { Standard Coefficients } \\
\text { BETA }\end{array}$ & T & Significance Level \\
\hline Fixed & 13.590 & 44.499 & & 0.305 & 0.762 \\
Exchange Rate Changes & -1.770 & 0.725 & -0.361 & -2.443 & 0.019 \\
Interest Rate Changes & -0.994 & 0.964 & -0.265 & -2.030 & 0.031 \\
The Size of Banks & -2.867 & 3.367 & -0.161 & -0.851 & 0.399 \\
Financial Leverage & 28.892 & 31.046 & 0.152 & 0.931 & 0.357 \\
Liquidity Ratio & -53.278 & 35.446 & -0.241 & -1.503 & 0.140 \\
\hline
\end{tabular}

\section{Discussion and Conclusion}

The present study set out to investigate the effect of market structure and risk taking on the efficiency of banks accepted in Tehran Stock Exchange. The positive effects of market structure and risk taking in promotion of efficiency of banks accepted in Exchange Stock were considered in this study. Results indicated a statistically significant relationship between market structure, risk taking, and efficiency of accepted banks. Thorough identifying organizational characteristics by which we can predict the nature of pricing and competition in markets, we can move towards improving organizational activity. The banks are considered as financial institutions that gather assets from different sources and provide them for sectors with liquidity needs. Therefore, the banks comprise the lifeblood of any country's economic system. In parallel with the entry of private banks into the financial markets, the demand for banking products and services has increased dramatically. The economic growth and development of each country require suitable transfer of additional financial resources from savers to investors. The existence of a broad and efficient financial market is critical where financial resources are located, lead to best investment positions. On the other, the greatest trading volume of country was achieved through banking system and the good performance of banking system has a crucial role in the recovery of economic activities. When the efficiency of the banks in terms of customer service is determined in comparison to the performance of banks acquiring profits, we see that the most of studied banks are efficient. The average amount of efficiency is the same for both concepts. The obtained 
results concerning the effect of market structure on the banks' efficiency confirmed the relationship between market structure and banks' efficiency. It also emphasized that the improvement of market structure increase the banks' efficiency and this increase is related more to the different banks' risk-taking or policies than the market structure. Therefore, the market structure within which banks operate had a significant effect on the banks' efficiency. Regarding the importance and effect of competition in the market on the banks' efficiency, we must increase the level of competition in the market system to improve the efficiency level, particularly in financial and credit institutions and the banking systems.

It is recommended to the investors to pay attention to inflation, exchange, and interest rate changes when they use the financial statements to make decisions with respect to investment in bank stocks or selling stocks. Considering the effect of inflation, exchange rate changes, and interest rate changes on bank performance, it is also suggested that the central bank provides more accurate information of the variables in close intervals so that it can shape the investors' potential and actual decisions for buying and selling stocks.

This study can be considered as the primary sources which have been done on the impact of market structure and risk-taking on the efficiency of banks in Iran. Given the importance of this issue as an important option in investing for shareholders and investors in different beneficiary groups and companies, some suggestions for further studies are proposed. Understanding the factors affecting the efficiency of performance of investors in addition to maintenance of bank's growth lead to enhanced profitability and satisfaction of shareholders of bank's policies. Therefore, investigating the other effective factors on banks' efficiency can be helpful for shareholders and investors decisions. Furthermore, this study could be conducted with accepted companies in Tehran Stock Exchange based on the type of industry for an extended period of time until the effect of market structure and risk-taking on the efficiency become more tangible. This study can also be replicated to examine the relationship between financial flexibility and market structure and its effect on banks' risks. Moreover, the effect of growth opportunities on banks' efficiency and the effect of capital structure on the cost of capital with emphasis on risk-taking could be estimated.

There were some limitations in the implementation and collection of related literature of the present study such as lack of access to information, lack of presenting suitable services from Stock Exchange, lack of access to the university library for references, loss of information concentration, lack of information process which causes for wasting time, lack of suitable access to this types of information, lack of accepted banks' financial statements in a period less than one year (e.g. quarterly or monthly) for carrying out more detailed research, calculating liquidity risk and banks' financial transparency information, estimating disclosure of bank risk models and sufficient information for calculating bank risks including liquidity risk in accepted banks of Tehran Exchange Stock. The next limitation of this study is related to the weakness of information in accepted banks of Stock Exchange concerning the calculation of liquidity risk which is due to the lack of accurate and reliable division of financial assets and debts. The time period of this study were from 2009 to 2013; therefore, we cannot generalize the results of this study to other populations in years before 2009 .

\section{References}


Bagherzadeh, S. (2003). Knowledge of corporate capital structure in listed companies in Tehran Stock Exchange. Journal of Financial Research, 16, 23-47.

Brander, J., \& Lewis, T. (1986). Oligopoly and financial structure: The limited liability effect. American Economic Review, 76(5), 956-970.

Bremus, F. M. (2015). Cross-border banking, bank market structures and market power: Theory and cross-country evidence. Journal of Banking \& Finance, 50(1), 242-259.

Chevalier, J. A. (1993). Capital structure and product market competition: Empirical evidence from the supermarket industry. American Economic Review, 85(3), 415-435.

Chung, K. H., \& Chuwonganant, C. (2014). Uncertainty, market structure, and liquidity. Journal of Financial Economics, 113, 476-499.

Claeys, S., \& Vander Vennet, R. (2008). Determinants of bank interest margins in central and Eastern Europe: A comparison with the West. Economic Systems, 32(2), 197-216.

Daryabar, F., Dehghantanha, A., \& Udzir, N. (2011). Investigation of bypassing malware defenses and malware detections. Paper presented at the Seventh International Conference on Information Assurance and Security (IAS), Malacca, Malaysia.

Demirguc-Kunt, A., Laeven, L., \& Levine, R. (2004). Regulations, market structure, institutions, and the cost of financial intermediation. Journal of Money, Credit, \& Banking, 36(3), 593-622.

Elrod, T., Russell, G. J., Shocker, A. D., Andrews, R. L., Bacon, L., Bayus, B. L., ... Shankar, V. (2002). Inferring market structure from customer response to competing and complementary products. Marketing Letters, 13(3), 221-232.

Heffernan, S. (2005). Modern banking. West Sussex: John Wiley \& Sons, Ltd.

Jerbashian, V. (2011).The telecommunications industry and economic growth: How the market structure matters. CERGE-EI Working Paper Series (ISSN 1211-3298).

Jolly, C. M. (1998). Market structure of food markets in Haiti: Myths and reality. Journal of Food Products Marketing, 5(1), 67-82.

Kapopoulos, P., \& Siokis, F. (2005). Market structure, efficiency, and rising consolidation of the banking industry in the Euro area. Bulletin of Economic Research, 57(1), 67-91.

Maksimovic, V. (1988). Capital structure in repeated oligopoly. The Rand Journal of Economics, 19(3), 389-407.

Maudos, J., \& De Guevara, J. (2007). The cost of market power in the European banking sectors: Social welfare cost versus cost inefficiency. Journal of Banking \& Finance, 31, 2103-2125.

Pandey, I. M. (2004). Capital structure, profitability, and market structure: Evidence from Malaysia. Asia Pacific Journal of Economics \& Business, 8(2), 78-91.

Tregenna, F. (2009). The fat years: The structure and profitability of the US banking sector in the pre-crisis period. Cambridge Journal of Economics, 33(4), 609-632. 